\title{
Research
}

\section{Correlation of EGFR, RAS, ERK and Ki-67 as predictor of inverted papilloma malignancy transformation}

\author{
Sonny Soebjanto*, Pudji Rahaju*, Hendradi Surjotomo*, Arif Satria Hardika** \\ *Department of Otorhinolaringology Head and Neck Surgery \\ **Department of Anatomical Pathology \\ Faculty of Medicine, Universitas Brawijaya/Dr. Saiful Anwar Hospital, \\ Malang
}

\begin{abstract}
Background: Inverted papilloma (IP) is benign tumor of the nasal cavity and paranasal sinuses epithelium. Sinonasal squamous cell carcinoma (SCC) is epithelial malignancy of nasal cavity and paranasal sinuses. HPV increases epidermal growth factor receptor (EGFR) expression mediated by E5. RAS is part of the RAS-RAF-MEK-ERK pathway that regulates various cell functions. Ki-67 serves as a molecular marker of tumor proliferation. Early malignant transformation often goes unnoticed. It is important to know the roles of EGFR, RAS, ERK and Ki-67 as predictor for tumor markers in IP and Sinonasal SCC. Objective: To find out the correlation of EGFR, RAS, ERK expressions towards Ki-67 expression as predictor of sinonasal IP transformation into sinonasal SCC. Method: A cross sectional study taking samples from the medical record of Dr.Saiful Anwar Hospital. The expression of EGFR, RAS, ERK and Ki-67 were examined with immunohistochemistry. Result: The estimated inner model results for direct influence of EGFR, RAS, ERK and Ki-67 towards IP and SCC were 2.352, 2.019, 2.625, and 2.213. The estimated inner model results for direct influence of EGFR, RAS and ERK towards Ki67 were 2.386, 3.811, and 3.00. Discussion: Previous research had reported an increase in Ki-67 index indicated the role of Ki-67 in cell tranformation of IP with dysplasia into SCC. Conclusion: EGFR, RAS and ERK expressions related to Ki-67 on IP and SCC. Increased expressions of EGFR, RAS, ERK and Ki-67 on IP indicated risk of malignant transformation. EGFR, RAS, ERK and Ki-67 could become predictors of IP transformation into SCC.
\end{abstract}

Keywords: inverted papilloma, sinonasal squamous cell carcinoma, EGFR, RAS, ERK, Ki-67

\begin{abstract}
ABSTRAK
Latar belakang: Papiloma inverted (PI) merupakan tumor jinak epitel kavum nasi dan sinus paranasal. Karsinoma sel skuamosa (KSS) sinonasal merupakan keganasan yang berasal dari epitel mukosa kavum nasi dan sinus paranasal. HPV meningkatkan ekspresi EGFR yang dimediasi oleh E5. $R A S$ merupakan bagian dari jaras RAS-RAF-MEK-ERK yang mengatur berbagai fungsi sel. Ki-67 berfungsi sebagai penanda molekuler proliferasi tumor. Diagnosis dini transformasi keganasan pada papiloma inverted seringkali luput dari pengamatan. Penting mengetahui peran EGFR, RAS, ERK dan Ki-67 sebagai cikal bakal penanda tumor pada IP dan KSS sinonasal. Tujuan: Mengetahui hubungan ekspresi EGFR, RAS, ERK terhadap Ki-67 sebagai prediksi transformasi keganasan PI sinonasal menjadi KSS sinonasal. Metode: Penelitian cross sectional, sampel penelitian diambil dari arsip rekam medis rawat jalan yang masih didapatkan preparat histopatologi papiloma inverted dan karsinoma sel skuamosa sinonasal di laboratorium Patologi Anatomi, dan dilakukan pemeriksaan ekspresi EGFR, RAS, ERK dan Ki-67 dengan imunohistokimia. Hasil: Hasil estimasi inner model untuk pengaruh langsung EGFR, RAS, ERK dan Ki-67 terhadap PI dan KSS sebesar 2,352, 2,019, 2,625 dan 2,213. Hasil estimasi inner model untuk pengaruh langsung EGFR, RAS dan ERK terhadap Ki-67 sebesar 2,386, 3,811 dan 3,00. Diskusi: Penelitian terdahulu membuktikan peningkatan indeks Ki-67 merupakan pertanda adanya peran Ki-67 pada perubahan PI dengan displasia menjadi SCC. Kesimpulan: Ekspresi EGFR,
\end{abstract}


RAS dan ERK berhubungan terhadap Ki-67 pada IP dan KSS. Peningkatan ekspresi EGFR, RAS, ERK dan Ki-67 pada PI menandakan adanya risiko terjadi transformasi keganasan. EGFR, RAS, ERK dan Ki-67 dapat menjadi cikal bakal prediktor transformasi keganasan PI menjadi KSS.

Kata kunci: inverted papilloma, karsinoma sel skuamosa sinonasal, EGFR, RAS, ERK, Ki-67

Correspondence address: dr. Sonny Soebjanto. Department of Otorhinolaryngology Head Neck Surgery, Faculty of Medicine, Brawijaya University / RSUD Dr. Saiful Anwar, Malang. Phone number: +6281230001982. Email: sonny.soebjanto@outlook.com.

\section{INTRODUCTION}

Sinonasal papilloma is a benign epithelial tumor of the nasal cavity and paranasal sinuses originating from Schneiderian membrane, an ectodermal sinonasal membrane of respiratory mucosa. The etiology of inverted papilloma (IP) is still unknown, but several hypotheses indicate the involvement of human papillomavirus (HPV) and other factors, such as chronic inflammation, environmental pollution and occupational exposure (welding fumes, nickel and organic solvents). ${ }^{1}$ Inverted papilloma (IP) and squamous cell carcinoma (SCC) diagnosis are often overlooked and have a significant degree of difficulty for otorhynolaringologists and anatomic pathologists, so that it raised the idea of finding prospects for molecular markers that will depict the diagnosis. In situ diagnosis, which is an early diagnosis of malignant transformation in IP and SCC, often overlooked due to limited staining that relies on hematoxylin eosin (HE), so that the clinician could hardly predict a good outcome in its management.

IP is generally diagnosed in white males in 5 to 7 decades, and SCC is more common in white males in 5 to 6 decades, where men are twice more than women. ${ }^{2}$ Previous research found that the average time for transformation of IP into SCC was 52 months. ${ }^{3,4}$ The study mentioned that $10 \%$ of Schneiderian papillomas transformed into sinonasal malignancies, and the most common synonasal malignancies was squamous cell carcinoma. Recent research has found the incidence of Schneiderian papillomas associated with sinonasal SCC is $5-10 \%$ with 0.33 cases per 1 million population per year. ${ }^{1}$

The imbalance between cell proliferation and apoptosis is one of the causes of tumor development. HPV infection plays an important role in the IP tumorigenesis. HPV integrates into host DNA, triggering tumorigenesis induced by oncoproteins E6 and E7. E6 binds to p53 via Adenosine Tri Phosphate (ATP) causing degradation and inactivation of p53. E7 binds and inactivates $\mathrm{pRb}$ with end result inducing $\mathrm{p} 16$, which plays a role in regulating the cell transition from the G1-S phase. HPV increases expression of Epidermal Growth Factor Receptor (EGFR) by means of an E5-mediated transcription enhancement mechanism. There is an increase in EGFR expression associated with highgrade dysplasia and malignancy, indicating that anti-EGFR therapy may play a role in reducing the risk of malignant transformation in IP. ${ }^{1}$

EGFR, RAS and ERK oncogens play an important role in head and neck squamous cell carcinoma (HNSCC). RAS gene which function as a GTPase molecule in regulating the activation of GDP and GTP. RAS gene role in the cell cycle is very important, because it is part of RAS-RAF-MEK-ERK pathway that regulates various types of cell functions. Mutations in RAS gene occur in various types of tumors and have been known for decades. Mutations that occur are mutations that act 
as oncogene activators. In various organs and tumors, mutations are mostly found in codons 12,13 and $61 .^{5}$

Extracellular signal regulatory protein kinase (ERK) is an important factor in regulating cell proliferation, differentiation and cell cycle. Previous study indicated that once body presented constitutive activation of ERK, cell proliferation may be enhanced. This is mainly dependent on ERK activation status. The constitutive activation of ERK has synergistic effects with other signal transduction pathway, participating in cell to facilitate cell survival or to induce cell death. ERK gene is found in myeloma, stomach, liver and prostate cancer. In addition, ERK expression is strongly associated with $\mathrm{Ki}$ 67 in poorly differentiated cells, indicating association of ERK with development of cancer proliferation. ${ }^{6,7}$

Previous study showed as on marker for cell proliferation, $\mathrm{Ki}-67$ indicate proliferation of nasopharyngeal carcinoma cells, and predict the prognosis. There were higher positive rate of ERK and Ki-67 positive rate in nasopharyngeal carcinoma patient tumor tissues than those in adjacent or control tissues. These indicated up-regulation of ERK and $\mathrm{Ki}$ 67 in nasopharyngeal carcinoma patients. When ERK signal transduction pathway in nasopharyngeal carcinoma patients is continuously activated, ERK can modulate occurrence and progression of nasopharyngeal carcinoma. ${ }^{6}$

A cohort study of 70 patients found an increase in Ki-67, p27 and PCNA in IP with SCC transformation compared with IP without SCC transformation. ${ }^{1}$ A research examined the role of biomolecular in malignant transformation and found that EGFR, RAS and ERK oncogens play a role in head and neck squamous cell carcinoma (HNSCC). ${ }^{5}$ Many studies have found EGFR, RAS, ERK and Ki-67 involvement in head and neck cancer. Meanwhile, very few studies have learned the involvement of EGFR, RAS, ERK and Ki-67 on both IP and SCC. Therefore the researchers wanted to find out whether EGFR, RAS, ERK and Ki-67 could be used as prospective tumor markers in the pathomechanism in the transformation of IP into SCC.

\section{METHOD}

This was an observational analytic study with a cross-sectional approach, where examination of epidermal growth factor receptor (EGFR), Kirsten rat sarcoma (KRAS), extracellular signal-regulated kinase (ERK) and Ki-67 expression on sinonasal inverted papilloma and sinonasal squamous cell carcinoma were performed. We could found signs of IP dysplasia such as atypical cells, squamous differentiation, extracellular or intracellular keratin formation (pink cytoplasm, disceratotic cells) and or intercellular bridges. Tumors were arranged in nests, masses or as small groups of cells or individual cells. The invasion was found to be irregular. Desmoplastic stromal reactions were common.

This research was conducted after obtaining ethical clearance, by taking paraffin blocks and histopathology specimens for reexamination at the Anatomical Pathology Laboratory Dr. Saiful Anwar Malang. Ethical clearance was obtained from the Ethics Committee of Faculty of Medicine, Brawijaya University (No.400/165 /K.3 /302 12018). Samples were taken from patients who were biopsied and data were obtained from the inpatient and outpatient of Oncology Clinic medical records in the Anatomical Pathology Laboratory of RSUD dr. Saiful Anwar from the period of January $1^{\text {st }} 2016$ to December $31^{\text {st }} 2017$. Samples were sent to the Anatomical Pathology Laboratory of the Faculty of Medicine, Universitas Brawijaya for immuno-histochemistry reexamination. 
This study was using total sampling technique. The inclusion criteria were paraffin biopsy/postoperative tissue blocks from patients with IP and SCC during the period of January $1^{\text {st }}, 2016$ to December $31^{\text {st }} 2017$ taken from the Anatomic Pathology of dr. Saiful Anwar Hospital, and diagnosed with IP and SCC, patients with SCC who had not received radiotherapy nor chemotherapy before surgery, and paraffin biopsy/postoperative tissue block of patients with recurrence of IP and SCC.

Tissue parts were fixed in neutral buffer formalin and embedded in paraffin. Then, they were deparaffinized, as well as sequentially rehydrated using xylol, absolute ethanol, 90\% ethanol, $80 \%$ ethanol, $70 \%$ ethanol, sterile distillated aqua, 3\% H2O2, and blocking buffer. The tissue parts were examined with Rabbit polyclonal EGFR (Cat No. bs-0165R, Bioss, Woburn, USA) KRAS (Cat No. bs1033R, Bioss, Woburn, USA), ERK (Cat No. bs-1020R, Bioss, Woburn, USA) and Ki-67 (Cat No. bs-2130R, Bioss, Woburn, USA), then incubated overnight at $40^{\circ} \mathrm{C}$. After incubation, they were thoroughly washed with phosphate buffer saline (PBS) for 5 minutes and repeated three times. Subsequently, the tissue parts were incubated with secondary antibody at room temperature for 60 minutes, then with horseradish peroxidase at room temperature for 40 minutes. Reaction products were visualized by diaminobenzidine (Nichirei Bioscience Inc, Tokyo, Japan) and hematoxylin. Then, cells expressing EGFR, KRAS, ERK and Ki-67 in the form of cells with a flat, brownish core were observed manually under microscope in 5 fields of view with 400x magnification by researchers and anatomical pathologists at Anatomical Pathology Laboratory of dr. Saiful Anwar Hospital Malang. Lastly, the mean scores were collected.

General and clinical characteristics of patients were descriptively analyzed and Chi square test was used for testing relationships between categorical variables. The correlation between EGFR, KRAS, ERK and Ki-67 expression on Sinonasal IP and SCC was tested using T-independent test, if the distribution were not normal then Mann Whitney test was used, $p$ value $<0.05$ was considered significant. The correlation between EGFR, KRAS and ERK towards Ki67 expression on sinonasal IP and SCC was tested using Path analysis test, $t$ value $>1.96$ was considered significant.

All data obtained were processed using Microsoft Office 2010 program Statistical Package for Social Sciences (SPSS) version 23.0 and Smart Partial Least Square 2.0.

\section{RESULT}

This study involved 21 inverted papilloma patients and 6 sinonasal squamous cell carcinoma patients as research subjects. General characteristics of research subjects including gender, age group, education and type of work were listed in table 1.

Table 1. General Characteristics of Research Subjects

\begin{tabular}{|c|c|c|c|c|c|}
\hline \multirow[t]{2}{*}{ General Characteristics } & \multicolumn{2}{|c|}{$\mathrm{IP}(\mathrm{n}=\mathbf{2 1})$} & \multicolumn{2}{|c|}{$\operatorname{SCC}(n=6)$} & \multirow[t]{2}{*}{$\mathbf{P}$} \\
\hline & $\mathbf{n}$ & $\%$ & $\mathrm{n}$ & $\%$ & \\
\hline \multicolumn{6}{|l|}{ Age group } \\
\hline No data & 1 & 4.8 & 0 & 0.0 & 0.852 \\
\hline Early adulthood (25-35years) & 2 & 9.5 & 1 & 16.7 & \\
\hline Late adulthood (36-45years) & 5 & 23.8 & 1 & 16.7 & \\
\hline Early elderly (46-55years) & 3 & 14.3 & 2 & 33.3 & \\
\hline Late elderly (56-65years) & 7 & 33.3 & 1 & 16.7 & \\
\hline Seniors ( $>65$ years $)$ & 3 & 14.3 & 1 & 16.7 & \\
\hline \multicolumn{6}{|l|}{ Gender } \\
\hline Male & 14 & 66.7 & 5 & 83.3 & 0.430 \\
\hline Female & 7 & 33.3 & 1 & 16.7 & \\
\hline
\end{tabular}




\section{Education}

No data

Elementary school

Junior high school

Senior high school

College

Profession

Does not work

Work

Note: tested with chi square test

$\begin{array}{ccc}4.8 & 0 & 0.0 \\ 61.9 & 1 & 16.7 \\ 4.8 & 1 & 16.7 \\ 14.3 & 2 & 33.3 \\ 14.3 & 2 & 33.3 \\ & & \\ 19.0 & 0 & 0.0\end{array}$

0.303

6.7

3.3

0.0

$\begin{array}{lll}81.0 & 6 & 100.0\end{array}$

0.247

Patient age data showed a value of 0.852 ( $p>0.05)$, which meant that IP and SCC group had number of patients with no significant age group. Gender factor showed a value of 0.430 ( $p>0.05)$, which could be interpreted that IP and SCC group had same number of patients with same relative gender, because it did not show any significant differences. As well as education and employment factors, each showed a significance value of 0.303 and $0.247(p>0.05)$, where this could be interpreted that education and employment in the IP and SCC patients were not significantly different. Group of IP and SCC patients had an age group, gender, education, and occupation that were relatively homogeneous, which meant not significantly different.

Clinical characteristics of research subjects based on complaints, physical examination, Krouse classification, $\mathrm{T}$ classification and $\mathrm{N}$ classification were presented in table 2 .

Table 2. Clinical characteristics of research subjects

\begin{tabular}{|c|c|c|c|c|c|}
\hline \multirow[t]{2}{*}{ Clinical characteristics } & \multicolumn{2}{|c|}{$I P(n=21)$} & \multicolumn{2}{|c|}{$\operatorname{SCC}(n=6)$} & \multirow[t]{2}{*}{$\mathbf{p}$} \\
\hline & $\mathbf{n}$ & $\%$ & $\mathbf{n}$ & $\%$ & \\
\hline Complaint & & & & & \\
\hline Bloody nasal mucus & 18 & 66.7 & 6 & 22.2 & 0.326 \\
\hline Hearing loss & 0 & 0.0 & 0 & 0.0 & - \\
\hline Nasal congestion & 21 & 77.8 & 6 & 22.2 & - \\
\hline Neck bump & 0 & 0.0 & 1 & 3.7 & 0.057 \\
\hline \multicolumn{6}{|l|}{ Physical examination } \\
\hline Cranial nerves & 0 & 0.0 & 0 & 0.0 & - \\
\hline Ear & 0 & 0.0 & 0 & 0.0 & - \\
\hline Nose & 21 & 77.8 & 6 & 22.2 & - \\
\hline Throat & 0 & 0.0 & 0 & 0.0 & - \\
\hline Neck lymph node & 0 & 0.0 & 1 & 3.7 & 0.057 \\
\hline \multicolumn{6}{|l|}{ Krouse classification } \\
\hline Q1 & 1 & 4.8 & & & - \\
\hline $\mathrm{Q} 2$ & 6 & 28.6 & & & - \\
\hline $\mathrm{O} 3$ & 13 & 61.9 & & & - \\
\hline Q4 & 1 & 4.8 & & & - \\
\hline \multicolumn{6}{|l|}{ T classification } \\
\hline Q1 & & & 0 & 0.0 & - \\
\hline Q2 & & & 0 & 0.0 & - \\
\hline Q3 & & & 4 & 66.7 & - \\
\hline Q4 & & & 2 & 33.3 & - \\
\hline \multicolumn{6}{|l|}{ N classification } \\
\hline No & & & 5 & 83.3 & - \\
\hline $\mathrm{N} 1, \mathrm{~N} 2$ or $\mathrm{N} 3$ & & & 1 & 16.7 & - \\
\hline
\end{tabular}

p-value $<0.05$ was statistically significant, tested with chi square test.

Based on clinical characteristics, data research subjects showed that hearing loss, nasal congestion, cranial nerve palsy, earnose-throat examination, $\mathrm{T}$ classification ( $\mathrm{T} 1$ to T4), $\mathrm{N}$ classification (N0), $\mathrm{N}$ classification
(N1, N2 or N3) could not be analysed, because clinical data showed all patients experienced the same thing or nothing at all. Thus, it could be concluded that clinical characteristics of research subjects such as hearing loss, nasal 
congestion, cranial nerve palsy, ear- nosethroat examination, $\mathrm{T}$ classification ( $\mathrm{T} 1$ to T4), N classification (N0), N classification (N1, N2 or N3) between IP and SCC groups was not significantly different. The complaints of bloody nasal mucus $(\mathrm{p}=0.326)$ and lump in

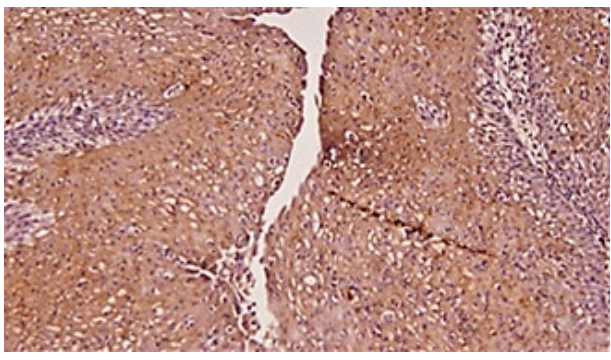

A

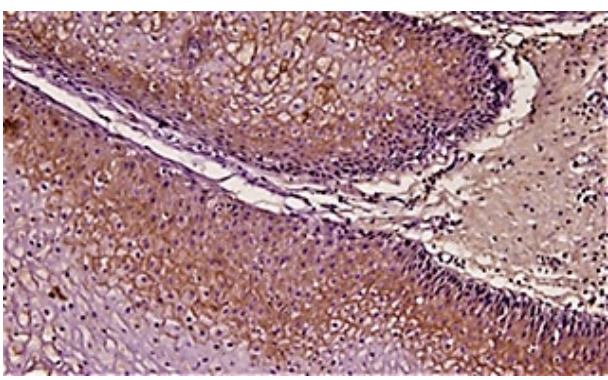

B

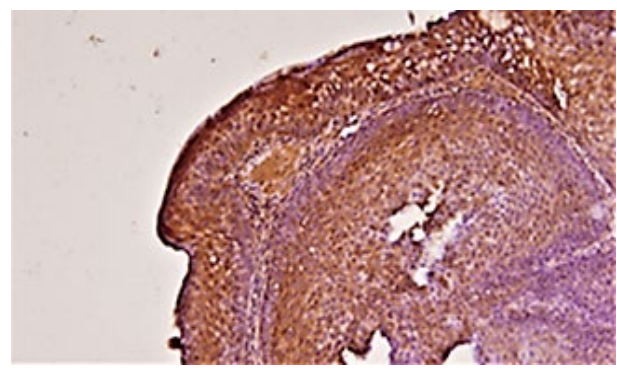

C

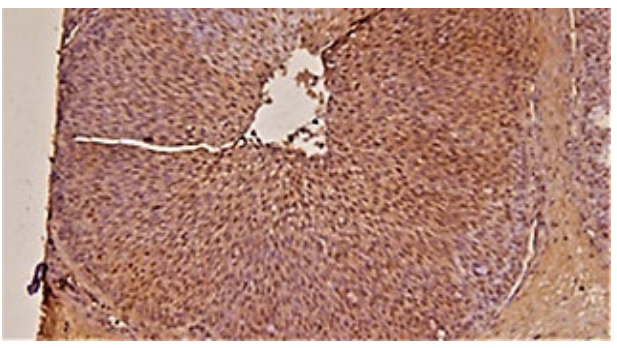

D the neck $(\mathrm{p}=0.057)$ had a value greater than $\alpha=0.05$, therefore it could be concluded that complaints of bloody nasal mucus, and lump in the neck between the IP and SCC was not significantly different.

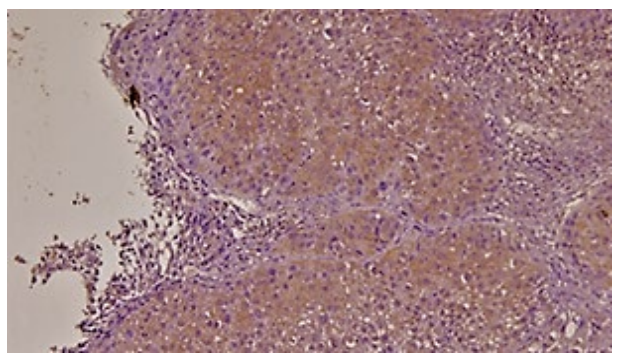

E

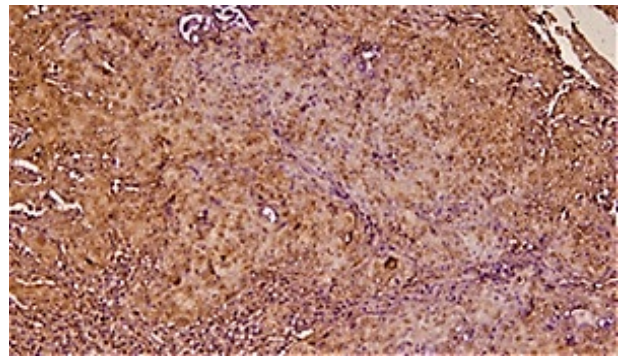

$\mathbf{F}$

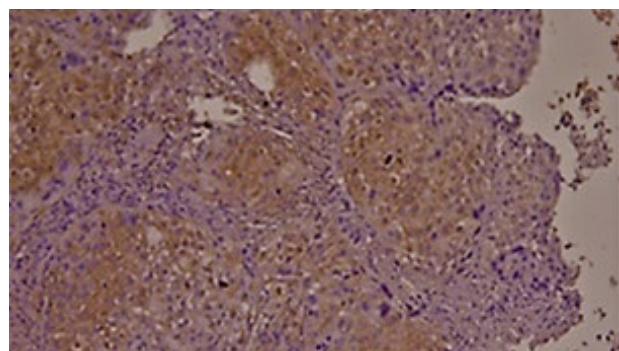

G

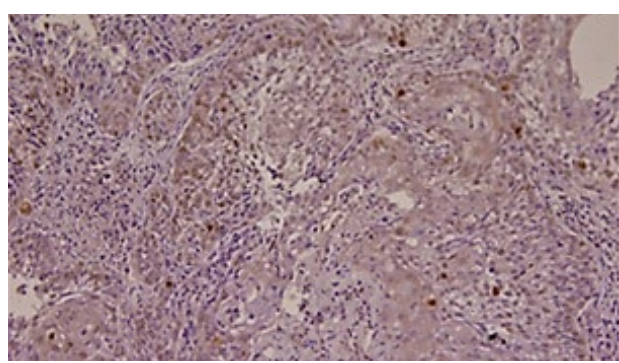

H

Figure 1. IP and SCC seen with 200x magnification.

(A) EGFR expression; (B) KRAS expression; (C) ERK expression; (D) Ki-67 expression; (E) EGFR expression; (F) KRAS expression; (G) ERK expression; (H) Ki-67 expression. 
Table 3. Data of normality test results

\begin{tabular}{lccc}
\hline \multicolumn{1}{c}{ Variable } & Statistic & p-value & Results \\
\hline EGFR & 0.839 & 0.001 & Data not normally distributed \\
KRAS & 0.897 & 0.011 & Data not normally distributed \\
ERK & 0.844 & 0.001 & Data not normally distributed \\
Ki-67 & 0.858 & 0.002 & Data not normally distributed \\
\hline
\end{tabular}

Based on Shapiro Wilk test, EGFR, KRAS, ERK, and Ki-67 in IP and SCC showed a significance value smaller than alpha 0.05 (p $<0.05$ ), thus it could be concluded that EGFR, KRAS, ERK, and Ki-67 data in IP and SCC group had an abnormal distribution. Hence, further testing could not be carried out using an independent sample $t$ test, but with Mann Whitney test.

Table 4. The comparison results of EGFR, KRAS, ERK and Ki-67 between IP and SCC group

\begin{tabular}{|c|c|c|c|c|c|c|c|}
\hline & \multicolumn{4}{|c|}{ Groups } & \multicolumn{2}{|c|}{ CI $95 \%$} & \multirow{3}{*}{$\begin{array}{c}\text { p value of } \\
\text { Mann Whitney }\end{array}$} \\
\hline & \multicolumn{2}{|c|}{ IP $(n=21)$} & \multicolumn{2}{|c|}{$\operatorname{SCC}(n=6)$} & \multirow[b]{2}{*}{ Down } & \multirow[b]{2}{*}{ Up } & \\
\hline & Mean & $\pm \mathrm{SD}$ & Mean & $\pm \mathrm{SD}$ & & & \\
\hline EGFR & 37.86 & 17.51 & 46.67 & 27.51 & 31.95 & 47.68 & 0.613 \\
\hline KRAS & 50.95 & 20.47 & 57.5 & 20.43 & 44.39 & 60.42 & 0.459 \\
\hline ERK & 29.76 & 9.42 & 42.5 & 25.25 & 26.73 & 38.46 & 0.472 \\
\hline $\mathrm{Ki}-67$ & 20 & 6.71 & 34.17 & 13.2 & 19.11 & 27.18 & 0.012 \\
\hline
\end{tabular}

Based on the table above, the average EGFR, KRAS, ERK, and Ki-67 in the IP group were lower than the average EGFR, KRAS, ERK, and Ki-67 in the SCC group. Mann Whitney test result for EGFR, KRAS, and ERK between IP and SCC group showed a significance value of $0.613,0.459$ and 0.472 ( $>>0.05$, accept Ho), which means that EGFR, KRAS, and ERK between IP patients group and the SSC group were not significantly different. This was because the difference in EGFR, KRAS, and ERK between IP and SCC groups were not too large, and statistically the differences were not significant.

While Mann Whitney test results for Ki-67 showed a significance value of 0.012 ( $p<0.05$, reject Ho), which means that Ki-67 between IP and SCC group was significantly different.

The inner model estimation results for direct influence of EGFR towards the group (IP and SCC) showed t-statistic value of 2.352, where the value was greater than 1.96 ( $t$ table) for two-way test with an error level

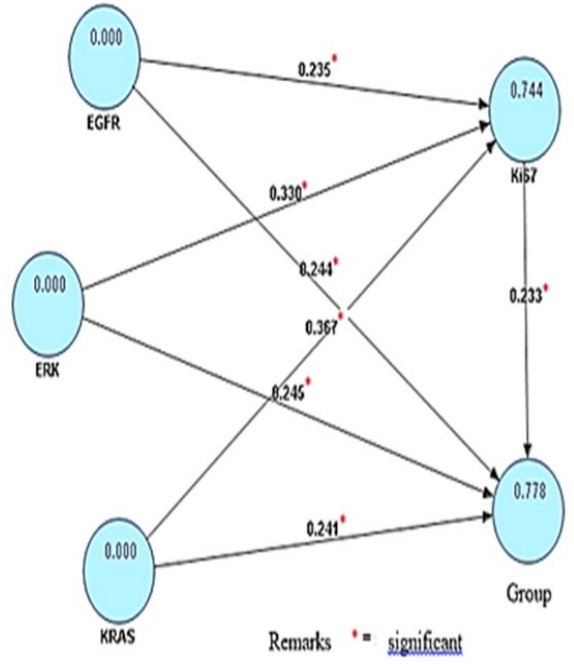

Figure 2. Path analysis results using partial least squares (PLS) regression.

$\alpha=5 \%$, this showed direct influence of EGFR on the group (IP and SCC) was significant. The result was positive with path coefficient of 0.244, which meant EGFR value in the SCC group tended to be higher than EGFR in the IP group. 
The inner model estimation results for direct influence of EGFR toward Ki-67 showed t-statistic value of 2.386 , where the value was greater than $1.96(\mathrm{t}$ table) for two-way test with an error level $\alpha=5 \%$, this showed direct influence of EGFR against Ki-67 was significant. The result was positive with path coefficient of 0.235 , which meant the higher the EGFR, Ki-67 would also increase. And vice versa, the lower the EGFR, Ki-67 would also decrease. This happened both in the IP patient group and in the SCC group.

The inner model estimation results for direct influence of ERK toward the group (IP and SSC) showed t-statistic value of 2.625, where the value was greater than $1.96(\mathrm{t}$ table) for two-way test with an error level $\alpha=5 \%$, this showed direct influence of ERK on the group (IP and SCC) was significant. The result was positive with path coefficient of 0.245 , which meant ERK value in the SCC group tended to be higher than ERK in the IP group.

The inner model estimation results for direct influence of ERK toward Ki-67 showed $\mathrm{t}$-statistic value of 3.00 , where the value was greater than 1.96 ( $\mathrm{t}$ table) for two-way test with an error level $\alpha=5 \%$, this showed direct influence of ERK against Ki-67 was significant. The result was positive with path coefficient of 0.330 , which meant the higher the ERK, Ki-67 would also increase. And vice versa, the lower the ERK, Ki-67 would also decrease. This happened both in the IP patient group and in the SCC group.

The inner model estimation results for KRAS direct influence toward the group (IP and SCC) showed t-statistic value of 2.019, where the value was greater than 1.96 ( $\mathrm{t}$ table) for two-way test with an error level $\alpha=5 \%$, this showed direct influence of KRAS on the group (IP and SCC) was significant. The result was positive with path coefficient of 0.241 , which meant KRAS value in the SCC group tended to be higher than KRAS in the IP group.
The inner model estimation results for KRAS direct influence toward Ki-67 showed t-statistic value of 3.811 , where the value was greater than 1.96 ( $\mathrm{t}$ table) for two-way test with an error level $\alpha=5 \%$, this showed direct influence of KRAS toward Ki-67 was significant. The result was positive with path coefficient of 0.367 , which meant that the higher the KRAS, Ki-67 would also increase. And vice versa, the lower KRAS, Ki-67 would also decrease. This happened both in the IP patient group and in the SSC group.

The inner model estimation results for the direct influence of Ki-67 toward the group (IP and SCC) showed t-statistic value of 2.213, where the value was greater than 1.96 ( $t$ table) for two-way test with an error level $\alpha=5 \%$, this showed direct influence of Ki-67 toward the group (IP and SCC) was significant. The result was positive with path coefficient of 0.233 , which meant value of $\mathrm{Ki}-67$ in the SSC group tended to be higher than Ki-67 in the IP group.

\section{DISCUSSION}

The comparison of male and female in IP research subjects was 14:7. IP was found to be more common in male than in female with a ratio of $2.8: 1 .^{8}$ While in the subjects of SCC, the ratio of male and female was $5: 1$. There had been an increased number of SCC cases occurring between the ages of 40 to 82 years with an average age of 60 years. ${ }^{9}$ This was inseparable from various etiological factors such as HPV / EBV virus infection, environment, and genetic factors that involved carcinogenic processes and mutations. A low level of education did not always result in lack of patient knowledge of the disease. Patients with higher education sometimes had insufficient understanding of health. Therefore, it is important to promote knowledge about health, in order to prevent delay in the management of the disease and hopefully could achieve good result. 
Nasal congestion complaints was reported in 53\% of SCC patients and bloody nasal mucus in $27 \%$ of SCC patients. ${ }^{4}$ Most of the patients did not immediately seek help and came to see a doctor, they ignored the sign and symptoms or tried alternative medicine first, so that patients who came to the hospital already had severe complaints or had entered the final stage. Nasal congestion accompanied with bloody nasal mucus were the most common complaints in IP and SCC group.

A study had reported an increase in $80 \%$ and $90 \%$ EGFR in IP and IP patients with metachronous carcinoma. ${ }^{10}$ There had been $45 \%$ increase in KRAS in patients with oral cavity squamous carcinoma. This indicated the involvement of KRAS in mitogenic signal transduction which resulted in an increase in cell cycle proliferation and regulation. ${ }^{11}$

There had been $80 \%$ increase of ERK in nasopharyngeal carcinoma (NPC) patients. This showed that ERK transduction pathway in patients with NPC was continuously activated, so that ERK could regulate the condition and progression of NPC. ${ }^{6}$ Research had reported an increase in the Ki-67 index in IP with mild dysplasia, IP with moderate dysplasia, IP with severe dysplasia and SCC with a ratio of $8.5: 9: 21.2: 26.5$. This increase in Ki-67 index showed the role of Ki-67 in cell transformation in IP with dysplasia in the transformation of IP into SCC. ${ }^{12}$

The inner model estimation results for the direct influence of EGFR towards the group (IP and SSC) showed t-statistic value of 2.352. A study had found 10-fold increase in EGFR in synchronous and metachronous carcinoma compared with IP and had also discovered an increase in EGFR in the epithelial basal cell cytoplasm. This showed the role of EGFR in the transformation of IP malignancy into SCC. ${ }^{10}$

The inner model estimation results for direct influence of EGFR towards Ki-67 showed t-statistic value of 2.386. A research had found direct relationship between Ki-67 and EGFR in breast carcinoma patients. Ki-67 acts as a prognostic factor for recurrence and indicates a poor prognosis in invasive ductal breast cancer (IDC). They also found that high Ki-67 expression on immunohistochemical examination was the strongest prognostic factor in predicting tumor recurrence and mortality at an advanced stage. ${ }^{12}$

The inner model estimation results for KRAS direct influence towards the group (IP and SCC) showed t-statistic value of 2.019. A study had reported significant differences in the KRAS gene mutation in patients with IP, IP with dysplasia and SCC. These findings indicated that KRAS mutation played a major role in the malignant transformation of the IP into SCC. ${ }^{13}$

The inner model estimation results for KRAS direct influence towards Ki-67 showed $\mathrm{t}$-statistic value of 3.811. A research had also found an increase in KRAS and Ki-67 in colorectal carcinoma patients. Ki-67 could be used as a molecular marker because Ki67 was positively correlated with the degree of histological differentiation in colorectal carcinoma. $^{14}$

The inner model estimation results for the direct influence of ERK towards the group (IP and SCC) showed t-statistic value of 2.625. A study had found an increase in ERK levels in the lips, tongue and pharynx malignancies. Increased ERK was associated with lymph node metastasis, proliferation and recurrence of head and neck malignancies. ${ }^{15}$

The inner model estimation results for direct influence of ERK towards Ki-67 showed t-statistic value of 3.00. A research had found an increase in ERK and $\mathrm{Ki}-67$ in NPC patients. When ERK transduction pathway was activated continuously, ERK could regulate the survival and progression of the NPC. ERK had a significant relationship with the cell proliferation index, in this case Ki-67 which was used as a molecular marker. ${ }^{6,15}$ 
The inner model estimation results for direct influence of $\mathrm{Ki}-67$ towards the group (IP and SCC) showed t-statistic value of 2.213. A research had concluded that $\mathrm{Ki}-67$ worked in the cell cycle and caused malignant transformation. Ki-67 initiated IP entry into the G1 cell cycle and influences CDK1 in causing malignant transformation. ${ }^{16}$

Conclusion of this study found that (1) Expression of EGFR, KRAS and ERK were related to $\mathrm{Ki}-67$ in IP and SCC. (2) Increased expression of EGFR, KRAS, ERK and Ki-67 in IP indicated the risk of malignant transformation. (3) EGFR, KRAS, ERK and Ki-67 could be considered as prospective predictor of IP malignant transformation into SCC.

\section{REFERENCE}

1. Re M, Gioacchini F, Bajraktari A, Tomasetti M, Kaleci S, Rubini C, et al. Malignant transformation of sinonasal inverted papilloma and related genetic alterations: a systematic review. Eur Arch Otorhinolaryngol. 2017; 274(8): 2991- 3000

2. Zimmer LA, Carrau RL. Neoplasms of the Nose and Paranasal Sinuses. In: Johnson JT, Rosen CA, editors. Bailey's Head\&Neck Surg Otolaryngology. 5th ed. Philadelphia: Lippincott Williams \& Wilkins. 2014. p. 2044-62.

3. von Buchwald C, Bradley PJ. Risks of malignancy in inverted papilloma of the nose and paranasal sinuses. Curr opin Otolaryngol Head Neck Surg. 2007; 15(2):95-8.

4. Yasumatsu R, Nakashima T, Sato M, Nakano T, Kogo R, Hashimoto K, et al. Clinical management of squamous cell carcinoma associated with sinonasal inverted papilloma. Auris Nasus Larynx. 2017; 44(1):98-103.

5. Hunt JL, Barnes L, Lewis JS, Mahfouz ME, Slootweg PJ, Thompson LD, et al. Molecular diagnostic alterations in squamous cell carcinoma of the head and neck and potential diagnostic applications. Eur Arch Otorhinolaryngol. 2014; 271(2):211-23.
6. Chen Y,Wu R, Wang J.Effects of ERK/MAPK signal transduction pathway on proliferation and apoptosis of nasopharyngeal carcinoma. Int J Clin Exp Med. 2017; 10(12):16367-73.

7. Maggioni D, Gaini R, Nicolini G, Tredici G, Garavello W. MAPKs activation in head and neck squamous cell carcinomas. Oncology Reviews. 2011; 5(4):223-31.

8. Kim K, Kim D, Koo Y, Kim C-H, Choi EC, Lee J-G, et al. Sinonasal carcinoma associated with inverted papilloma: a report of 16 cases. J Cranimaxillofac Surg. 2012; 40(4):e125-9.

9. Yamashita Y, Hasegawa M, Deng Z, Maeda H, Kondo S, Kyuna A, et al. Human papillomavirus infection and immunohistochemical expression of cell cycle proteins $\mathrm{pRb}, \mathrm{p} 53$, and $\mathrm{p} 16$ INK4a in sinonasal diseases. Infect Agent Cancer. 2015; 10(1):23.

10. Chao J-C, Fang S-Y. Expression of epidermal growth factor receptor in the inverted papilloma and squamous cell carcinoma of nasal cavity. Eur Arch Otorhinolaryngol. 2008; 265(8):917.

11. Asseel MG, Merza MS. The Role of K-Ras and PI3Kcb Expression in Oral Squamous Cell Carcinoma. Mustansiriya Dental J. 2018; 10(2):247-51.

12. Yan J, Liu X-L, Han L-Z, Xiao G, Li N-L, Deng Y-N, et al. Relation between Ki-67, ER, PR, Her2/neu, p21, EGFR, and TOP II- $\alpha$ expression in invasive ductal breast cancer patients and correlations with prognosis. Asian Pac J Cancer Prev. 2015; 16(2):823-9.

13. Yasukawa S, Kano S, Hatakeyama H, Nakamaru Y, Takagi D, Mizumachi T, et al. Genetic mutation analysis of the malignant transformation of sinonasal inverted papilloma by targeted amplicon sequencing. Int J Clinical Oncology. 2018:19.

14. Zlatian OM, Comănescu MV, Roşu AF, Roşu L, Cruce M, Găman AE, et al. Histochemical and immunohistochemical evidence of tumor heterogeneity in colorectal cancer. Rom J Morphol Embryol. 2015; 56(1):175-81.

15. Albanell J, Codony-Servat J, Rojo F, Del Campo JM, Sauleda S, Anido J, et al. Activated extracellular signal-regulated kinases: association with epidermal growth factor receptor/transforming growth factor 
$\alpha$ expression in head and neck squamous carcinoma and inhibition by anti-epidermal growth factor receptor treatments. Cancer Res. 2001; 61(17):6500-10.

16. Tsou Y-A, Huang H-J, Wang T-C, Tai C-J, Chen C-M, Chen CY-C. Evaluation of correlation of cell cycle proteins and $\mathrm{Ki}$ 67 interaction in paranasal sinus inverted papilloma prognosis and squamous cell carcinoma transformation. BioMed Res Int. 2014; 2014 Art ID 634945:1-16. 